\title{
RESÍDUOS DOS CEMITÉRIOS: CONTAMINAÇÃO AMBIENTAL E SAÚDE PÚBLICA
}

Ariádina Silva Menezes - ariadinasmenezes@yahoo.com.br

Fundação Mineira de Educação e Cultura (Universidade FUMEC)

Stéphanie Soares Rocha Dias Morais - stephaniesmorais@yahoo.com.br Fundação Mineira de Educação e Cultura (Universidade FUMEC)

Thais Rubião Pimenta - thaisrubiao@gmail.com

Fundação Mineira de Educação e Cultura (Universidade FUMEC)

Juliana da Silva e Mascarenhas Guedes - e-mail jsguedes@fumec.br Universidade Fernando Pessoa - PORTO - PORTUGAL Fundação Mineira de Educação e Cultura (Universidade FUMEC) 


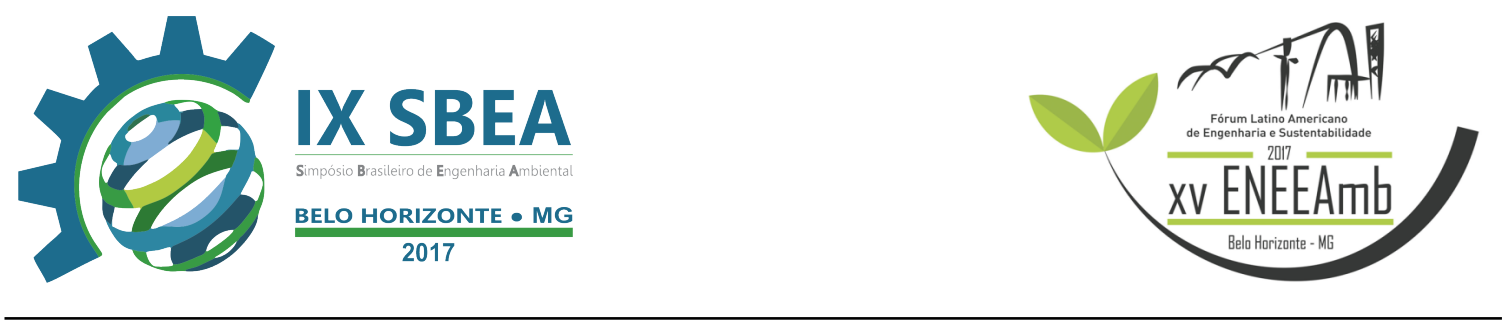

\section{RESUMO}

Com o crescente aumento da contaminação no solo, recursos hídricos e poluição atmosférica próximas aos locais de sepultamento, é inevitável desconsiderar os cemitérios como um grande problema relacionado à contaminação ambiental, mal gerenciamento de resíduos e propagação de doenças. $\mathrm{O}$ necrochorume, líquido composto por água, sais minerais e substâncias orgânicas, é o principal responsável pela contaminação do solo e aqüíferos subterrâneos. Diante disso, na tentativa de controlar essa situação, o Conselho Nacional do Meio Ambiente (CONAMA) publicou a Resolução $\mathrm{n}^{\circ} 335$, de 3 de abril de 2003, que prevê que todos os cemitérios devem ser submetidos ao processo de Licenciamento Ambiental. Visando a sustentabilidade urbana, este estudo foi desenvolvido com o objetivo de explorar a importância dos métodos de construção e de sepultamento de um cemitério, de modo que se tenha menor impacto ambiental e a preservação da saúde publica.

Palavras-chave: Cemitérios. Necrochorume. Contaminação. Solos. Lençóis freáticos. CONAMA 335/2003.

\section{INTRODUÇÃO/OBJETIVO}

Desde o início dos tempos, as pessoas tem o costume de enterrar seus mortos em lugares específicos. Chamamos os locais reservados ao sepultamento de cemitérios, que atualmente é a prática mais comum.

Os cadáveres, sofrem com processos de decomposição e apodrecimento, como a autólise que caracteriza-se por uma série de fenômenos fermentativos anaeróbicos e putrefação que é o processo de decomposição da matéria orgânica de bactérias, causando danos ao ambiente ao ter contato com o solo e lençóis freáticos (TORMEN; TASSO; KORF, 2017). Considera-se impacto ambiental "qualquer alteração das propriedades físicas, químicas e biológicas do meio ambiente" (CONAMA, 1986). 

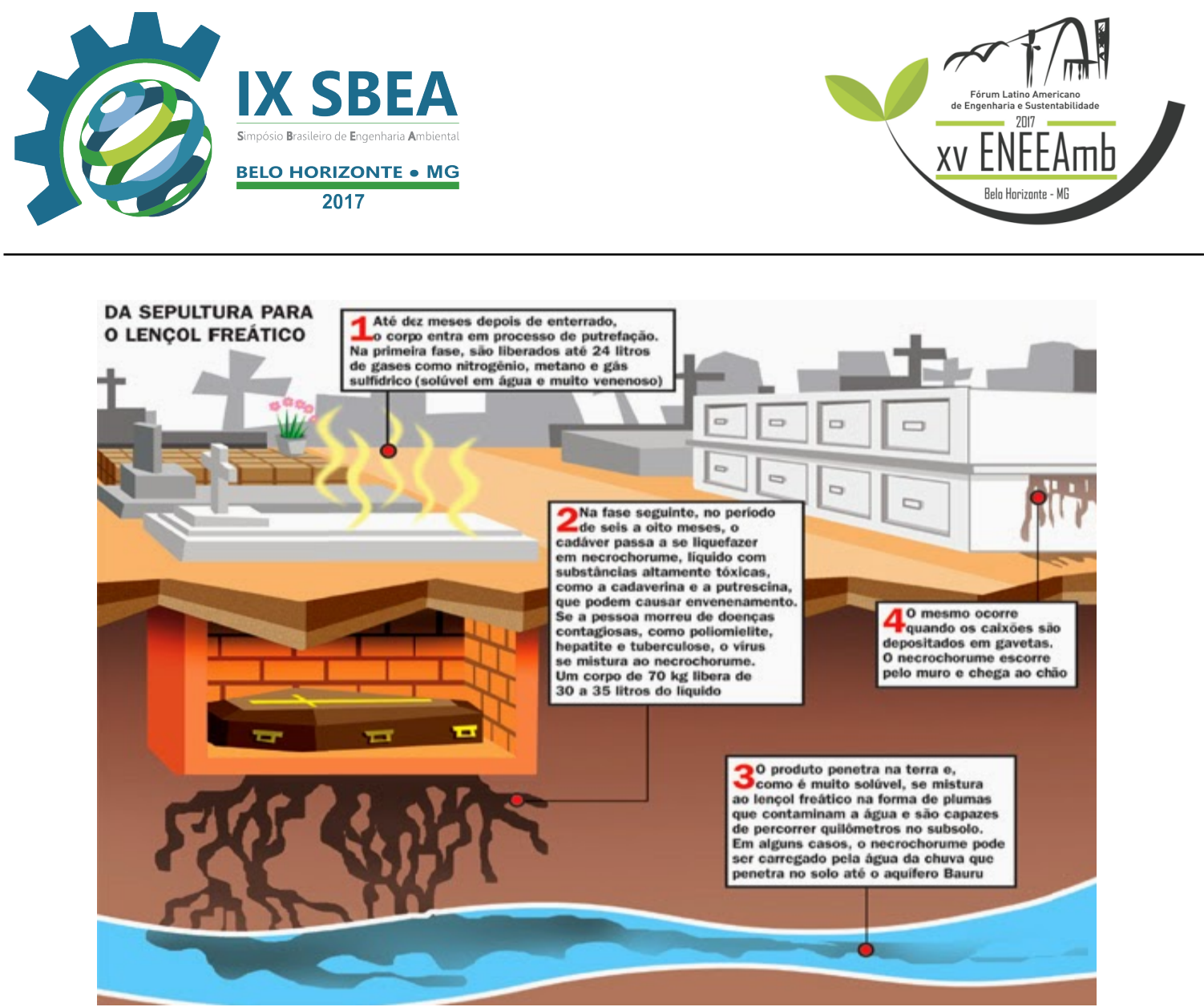

Imagem 1 - Processos de decomposição e apodrecimento e sua contaminação

Fonte: Tormen, Tasso e Korf (2017)

Grande parte das construções de cemitérios no Brasil são antigas e com ausência de planificação e foram construídos em locais onde o subsolo é bastante vulnerável, por possuírem características que facilitam a contaminação hídrica e do próprio solo. (SILVA et al., 2006)

Além disso com o aumento populacional ocorre-se também um crescente aumente de mortes nas últimas décadas, áreas destinadas ao sepultamento necessitam de constante expansão e adaptação para o atendimento da população. A escolha dessa localização, o método como é construído os cemitérios e a realização dos sepultamentos ainda se encontram inadequados em muitas cidades brasileiras.

Segundo pesquisa realizada pelo Jornal Semanal (2013), 75\% dos cemitérios brasileiros apresentaram problemas sanitários e ambientais, como solo inadequado para este fim e vazamento de necrochorume contaminando o lençol freático Essa situação é mais grave em casos onde os cemitérios foram construídos próximos de residências ou até mesmo 


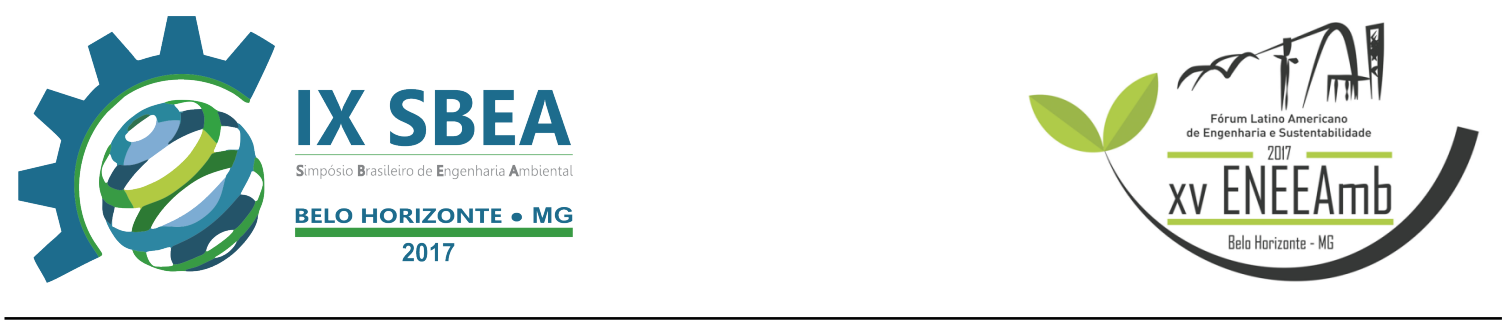

devido à urbanização que fez com que as residências chegassem ao entorno dos cemitérios.

Visto isso, a resolução do Conama número 335/2003 e 368/2006, determinaram que os cemitérios devem se adequar as novas regras em um prazo determinado.

A preocupação com a proximidade dos cemitérios com as residências vem desde o século XVIII, mas o pensamento de como a poluição causada pelos mesmos afeta o meio ambiental é atual. Segundo um relatório divulgado pela OMS (1998), os cemitérios são uma fonte potencial de poluição, podendo causar impactos ambientais no solo e lençóis freáticos em razão do vazamento de substâncias orgânicas e inorgânicas e microrganismos patogênicos.

Existem vários estudos em que os cemitérios podem ser comparados aos aterros sanitários, por ambos conterem matérias orgânicas e inorgânicas. Mas os cemitérios possuem um maior índice de contaminantes que podem levar à morte. (Santos, 2007)

Essa falta de planejamento dos cemitérios, afeta gravemente o meio ambiente e a saúde pública, visto que de acordo com Pedrosa (2014) a contaminação das águas por íons cloreto e nitrato, vírus, bactérias e necrochorume tornando-se um grande problema para os centros urbanos.

\section{METODOLOGIA}

O trabalho desenvolvido tem natureza básica, produzindo conhecimento a ser utilizado em outras pesquisas. Tem como objetivo uma pesquisa descritiva, pois define as características da população de pessoas em situação de rua da cidade de Contagem. Possui uma abordagem quantitativa requerendo o uso de recursos e técnicas, traduzindo tudo em números a partir de estudos estatísticos. Quanto aos procedimentos utiliza-se da rogativa de informações, por meio de análise quantitativa obtivemos conclusões 


\section{RESULTADOS E DISCUSSÃO}

A preocupação com os resíduos gerados por cemitérios é crescente, visto que de acordo com os microrganismos que atacam os tecidos em decomposição são capazes de produzir mais de 400 compostos químicos e gases.(BRAZ; BECKMANN; COSTA, 2000) Esses compostos são altamente perigosos e podem ocasionar a contaminação do solo, dos lençóis freáticos e poluir a atmosfera, afetando a qualidade da água subterrânea, do solo e do ar, colocando em risco o meio ambiente e a saúde pública. Porém, pouco se tem visto em ações que possam reparar ou cessar esses problemas.

Segundo (ALEXANDRINO, 2016), os cemitérios podem ser comparados aos aterros sanitários, por ambos conterem matérias orgânicas e inorgânicas. Todavia os resíduos orgânicos presentes nos corpos enterrados, tem a possibilidade de possuírem bactérias, além de sua decomposição liberar substâncias tóxicas. No caso dos cemitérios, esses resíduos orgânicos originam o necrochorume; líquido liberado pelo corpo na sua fase de decomposição, pela ação de microrganismos como vírus e bactérias.

É importante conhecer a composição do necrochorume para examinar seu comportamento no meio ambiente. O fluído contém aproximadamente $60 \%$ de água, $30 \%$ de sais minerais e $10 \%$ de substâncias orgânicas degradáveis. (KEMERICH; UCKER; BORBA, 2012). Esse fluído tem capacidade de infiltração do solo com ajuda hídrica podendo contaminar também os corpos d’água subterrâneos da região. Caso esses lençóis freáticos sejam fonte de captação de água pela população problema é intensificado, podendo propagar a contaminação para seres humanos e animais presentes na região, afetando a saúde. Essa contaminação pode desencadear doenças como tétano, gangrena gasoso, meta-hemoglobinemia, infecção alimentar, tuberculose, febre tifóide, febre paratifóide, disenteria bacilar e o vírus da hepatite tipo "A". (DOS SANTOS; MORAES; DE MORAIS NASCIMENTO, 2015)

Atualmente existem dois tipos de cemitérios; verticais e horizontais. Os cemitérios verticais são edifícios de um ou mais pavimentos, dotados de compartimentos destinados a sepultamento, eles eliminam o contato das águas subterrâneas com o necrochorume e não permite acumulo de água. Como é o caso no Memorial de Santos na imagem 1, no litoral de São Paulo. (FERRARI et al., 2015) 

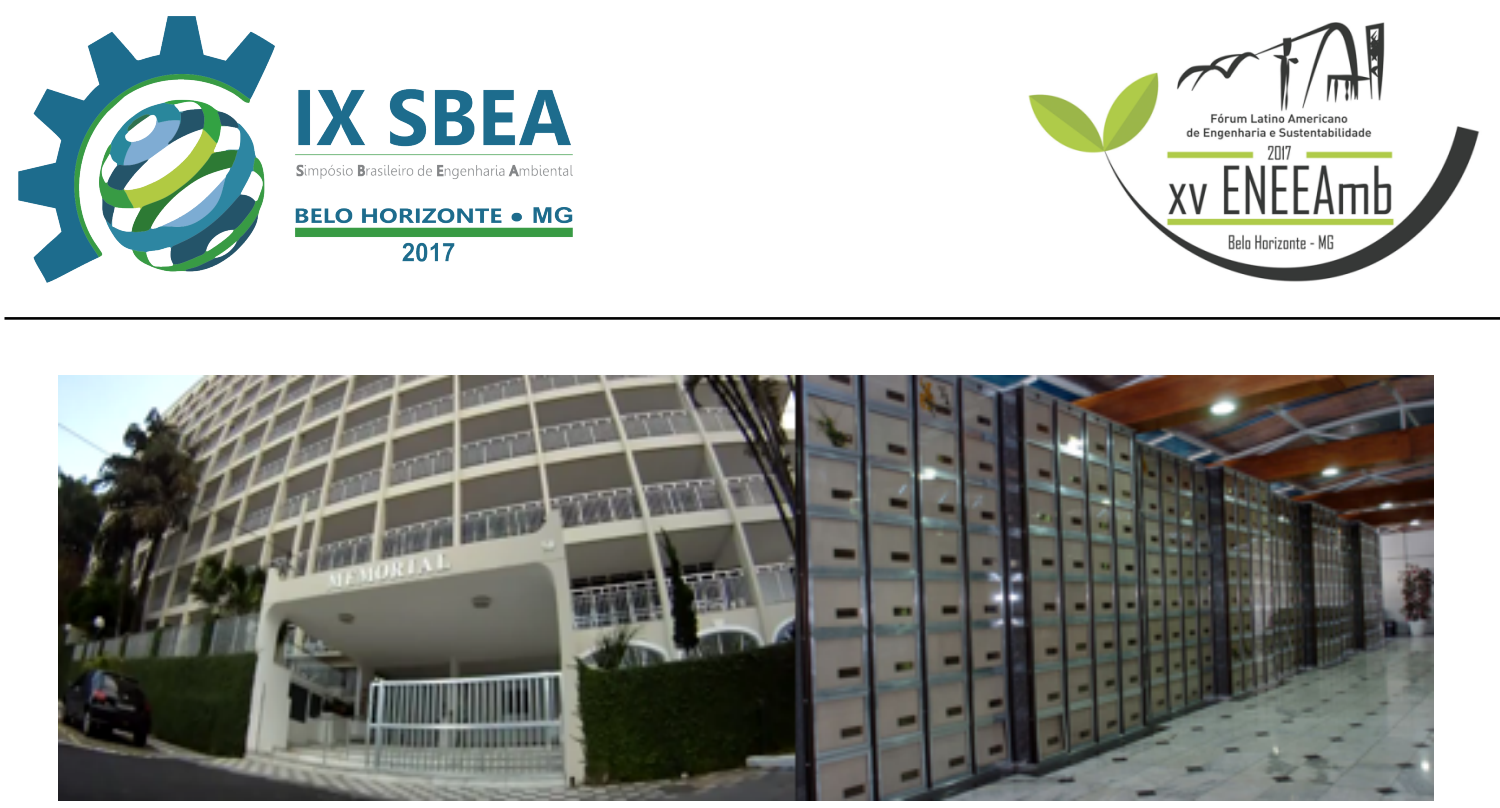

Imagem 2 - Memorial de Santos

Fonte: Ferrari et al (2015)

Já o cemitério horizontal é localizado em área aberta em forma de parques e jardins, como o cemitério do Bonfim, o mais antigo da cidade de Belo Horizonte e é reconhecido por seu valor histórico devido a seu grande acervo de esculturas e obras que ornam túmulos e mausoléus, ilustrado na imagem 2. (FERRARI et al., 2015)

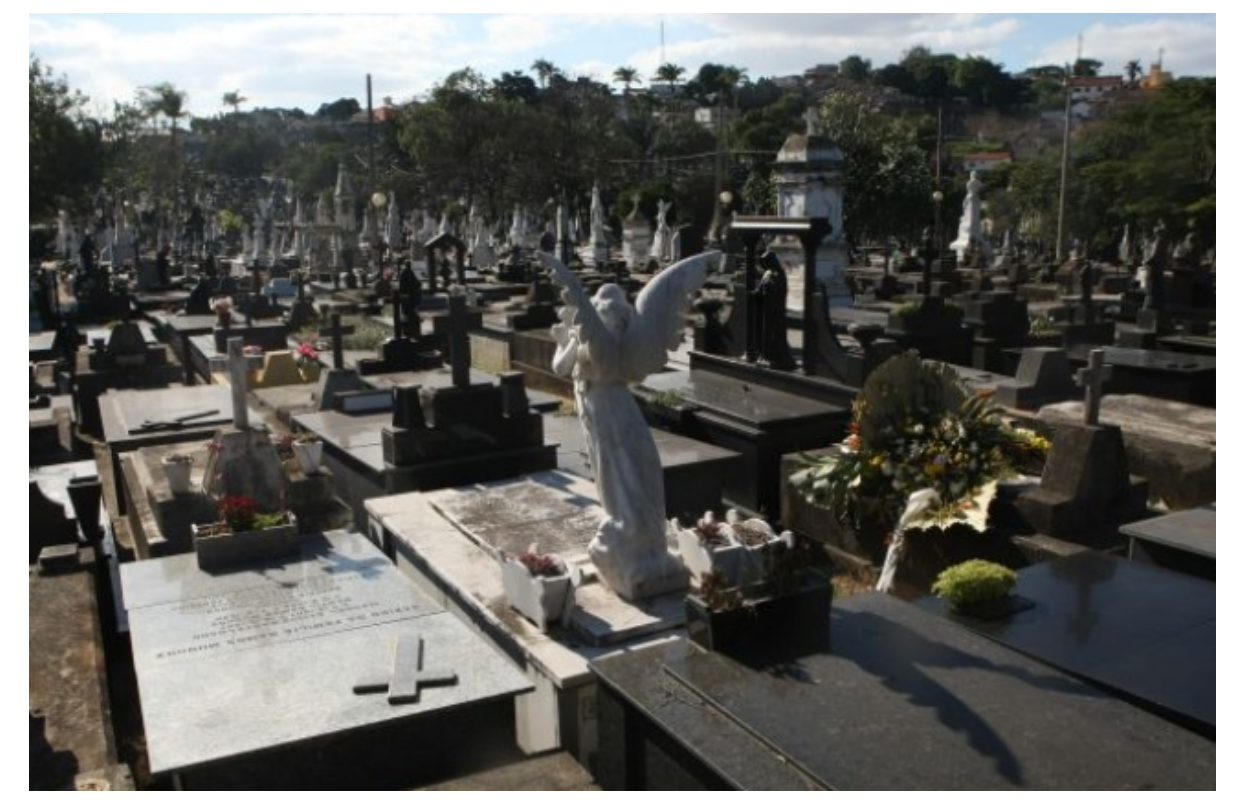

Imagem 3 - Cemitério do Bonfim

Fonte: (DE ALMEIDA, 2016)

À vista disso, a resolução Conama ${ }^{\circ} 335$, de 3 de abril de 2003 prevê no Art. $1^{\circ}$ que os cemitérios horizontais e os cemitérios verticais deverão ser sujeitos ao processo de licenciamento ambiental, nos termos desta Resolução. 


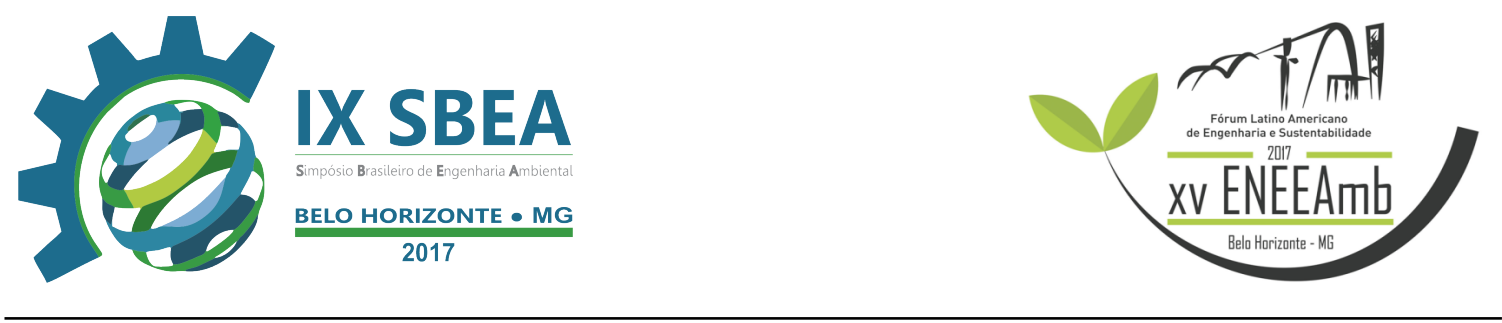

Antes da construção de um cemitério devem ser feitos diversos estudos e pesquisas quanto ao tipo de solo da região e a composição química do necrochorume. Os já existentes possuem áreas que muitas vezes têm características geológicas e hidro geológicas não avaliadas devidamente. As pesquisas devem ser específicas e detalhadas buscando prever o comportamento da substância nesse solo e prevenir suas possíveis conseqüências. É recomendado que o solo seja argiloso e não arenoso. (BRAZ et al., 2000)

Estudos revelam que solos argilosos dificultam a passagem do poluente aos aquíferos. Isso acontece, pois, os grãos de argila são muito pequenos e pouco porosos facilitando a absorção de água e outras substâncias químicas. Sendo assim, o vírus presente no poluente fica adsorvido nos grãos de argila o que dificulta sua chegada aos lençóis freáticos. Já nos solos arenosos e cascalhos o necrochorume pode alcançar os aquíferos com maior facilidade. (DOS SANTOS et al., 2015)

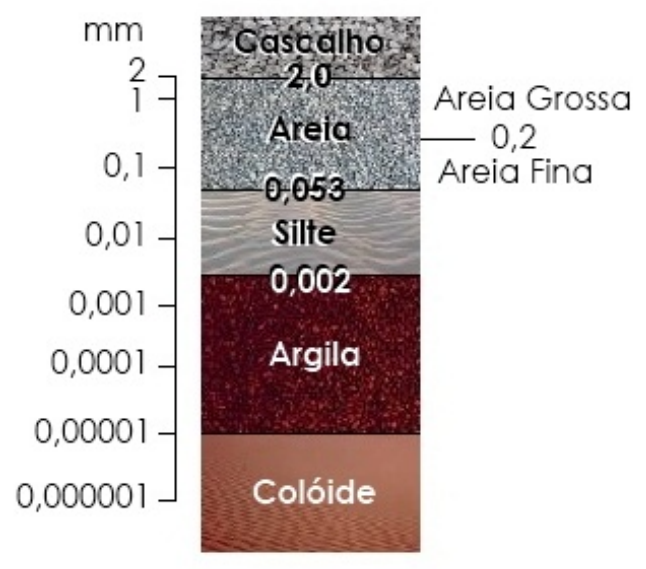

Imagem 4 - Escala de textura utilizada para solo

Fonte: Dos Santos et al (2015)

A incineração que é o processo de queimar os corpos mortos, é o procedimento que mais gera toxinas, mas os crematórios tem filtros muito específicos, o que faz com que esse método se torne o melhor para o meio ambiente, conforme o biólogo Valdir Rochinheski, "a cremação é a solução póstuma de menor impacto ambiental, pois não 


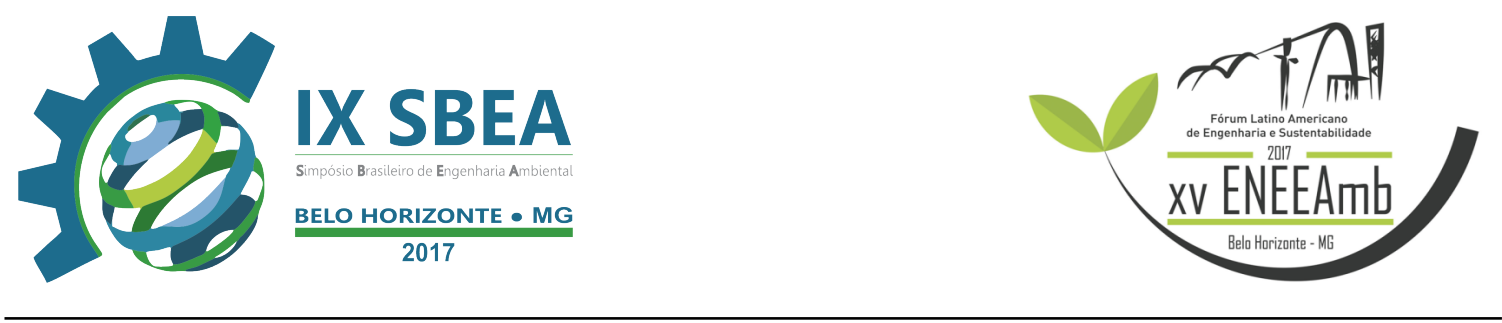

gera resíduos convencionais com potencial de contaminar o ambiente, tanto no solo quanto na atmosfera". (DA CUNHA KEMERICH et al., 2014)

De acordo com Pedrosa (2015), o solo em que os cemitérios estão instalados funciona como um filtro das impurezas depositadas sobre ele. A exposição de sepulturas mal conservadas a águas da chuva, provocando a enchente dessas e tornando os solos úmidos, ocasiona em um processo conhecido como saponificação no qual verifica-se a quebra das gorduras corporais e a liberação de ácidos graxos. Esses retardam o procedimento de decomposição do cadáver, tornando o processo de decomposição mais duradouro e mais contaminante ao solo e aqüíferos. (LELI et al., 2012)

Outro fator de preocupação é o material em que os caixões são fabricados. Esses devem ser fabricados com materiais que se decompõem em longo prazo e que não liberem substâncias químicas que afetem o meio ambiente. Segundo o biólogo Rochinheski (2013) os caixões construídos com madeiras não tratadas se decompõem em curtos prazos, permitindo uma rápida disseminação de líquidos da putrefação dos corpos, o que não é o ideal. Os caixões que contém metais e prata também provocam contaminação do solo por metais como ferro, cobre, chumbo, zinco e prata.

“Os corpos sepultados poderão estar envoltos por mantas ou urnas constituídas de materiais biodegradáveis, não sendo recomendado o emprego de plásticos, tintas, vernizes, metais pesados ou qualquer material nocivo ao meio ambiente. Parágrafo único. Fica vedado o emprego de material impermeável que impeça a troca gasosa do corpo sepultado com o meio que o envolve, exceto nos casos específicos previstos na legislação." (CONAMA, 2003).

Além dos metais e substâncias liberadas no mecanismo de decomposição, outro contaminante significativo é a radiação. Cadáveres que passaram por aparelhos com emissão de radiação podem estar contaminados. Nesse caso essa radiação também é liberada no solo. Para que esse risco seja reduzido é indispensável que seja feito com freqüência o controle de água nessas regiões. (TORMEN et al., 2017). 


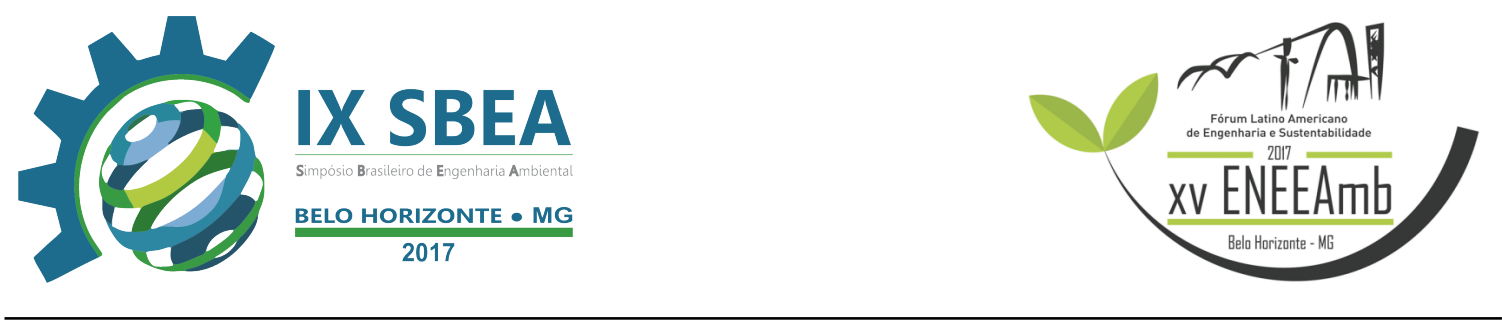

Quando houver a construção de novos cemitérios os órgãos ambientais municipais e estaduais tem a obrigação de licenciá-los e fiscalizá-los, conforme a resolução Conama 368/06 que recomenda a existência de uma distância entre o fundo da cova e o lençol freático, a depender da permeabilidade do solo. Já no caso de cemitérios antigos foi homologada a Resolução do Conama (402/2008) que estabeleceu prazo máximo até dezembro de 2010 para adequação ás novas regras.

A poluição atmosférica também é bastante preocupante, durante o processo de decomposição orgânica, além dos líquidos liberados há emissão também de gases, como o gás sulfídrico $(\mathrm{H} 2 \mathrm{~S})$, gás carbônico $(\mathrm{CO} 2)$, metano $(\mathrm{CH} 4)$, amônia $(\mathrm{NH} 3)$, entre outros descrito no Quadro 1. (KEMERICH et al., 2012)

Quadro 1 - Substâncias e suas conseqüências para o meio

\begin{tabular}{|c|c|c|}
\hline Substâncias & Nome & Responsável por \\
\hline $\mathrm{H} 2 \mathrm{~S}$ & Gás sulfídrico & $\begin{array}{l}\text { Odor nos cemitérios Afeta as } \\
\text { mucosas respiratória e ocular } \\
\text { provocando fortes irritações, } \\
\text { além de comprometer a saúde do } \\
\text { indivíduo. }\end{array}$ \\
\hline $\mathrm{CO} 2$ & Dióxido de carbono & Ocasionar o Efeito estufa \\
\hline $\mathrm{CH} 4$ & Metano & $\begin{array}{l}\text { Causar asfixia, parada cardíaca, } \\
\text { inconsciência e até mesmo danos } \\
\text { no sistema nervoso central. } \\
\text { Além de participar da formação } \\
\text { do efeito estufa. }\end{array}$ \\
\hline NH3 & Amônia & $\begin{array}{l}\text { Irritação nas vias respiratórias, } \\
\text { boca, garganta e estômago. Sua } \\
\text { inalação pode causar } \\
\text { dificuldades } \\
\text { respiratórias, inflamação } \\
\text { aguda do sistema respiratório. }\end{array}$ \\
\hline
\end{tabular}

Fontes: Adaptado de Kemerich at al. (2013) 


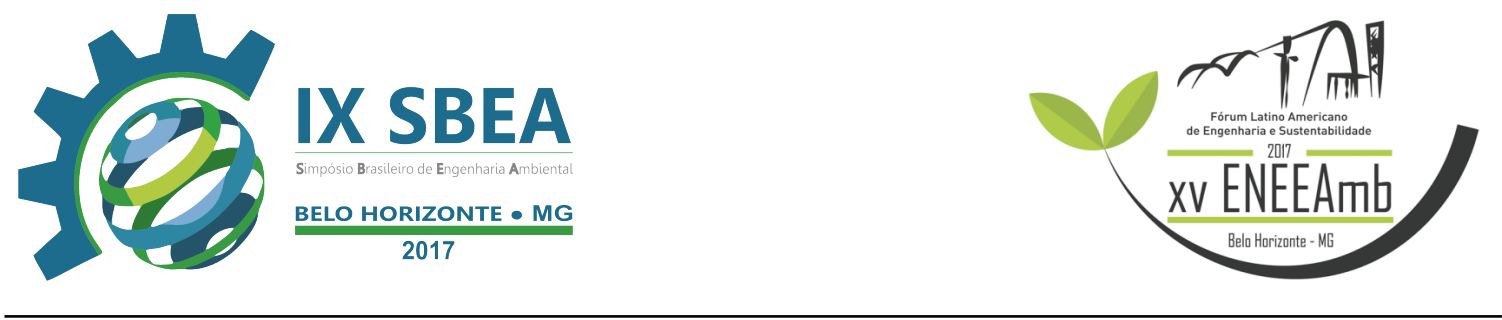

Além desses, outros gases são emitidos, como os óxidos metálicos (titânio, cromo, cádmio, chumbo, ferro, manganês, mercúrio e níquel entre outros), lixiviados dos adereços das urnas mortuárias, incluindo as substâncias formaldeído e metanol utilizados na prática do embalsamento. (KEMERICH et al., 2012).

Diante disso, a resolução número 335/2003 e 368/2006, determina que os cemitérios devem se adequar as novas regras em um prazo determinado. Uma forma de tentar que os órgão publicos protegessem os lençóis freáticos e mitigassem o problema da infiltração do necrochorume, se adequando as normas estabelecidas na resolução Conama 368/06.

Os resíduos de cemitérios podem ser reaproveitados como subprodutos para novas covas. O processo exige a separação das matérias, como podas de galhos, materiais recicláveis, vasos e flores descartáveis como mostrado na imagem 4 , e principalmente restos das construção civil, que estão geralmente misturados nos cemitérios. Há a utilização dos orgânicos como adubos através da compostagem e pelo uso dos demais resíduos como agregados para misturas de concreto na construção civil.(SILVA et al., 2006)

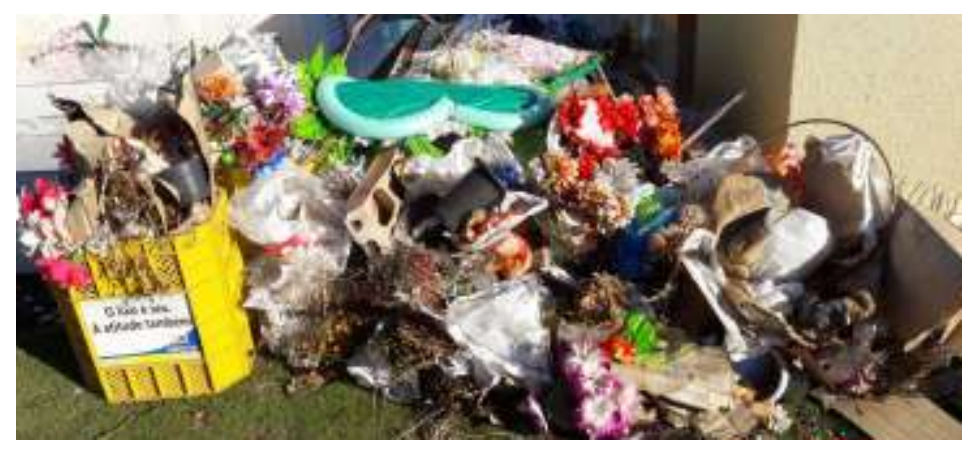

Imagem 5 - Lixos acumulados no cemitério de Maravilha Fonte: Silva et al. (2006)

\section{CONSIDERAÇÕES FINAIS/RECOMENDAÇÕES}

Com base na pesquisa feita, conclui-se que os cemitérios representam uma grande fonte 


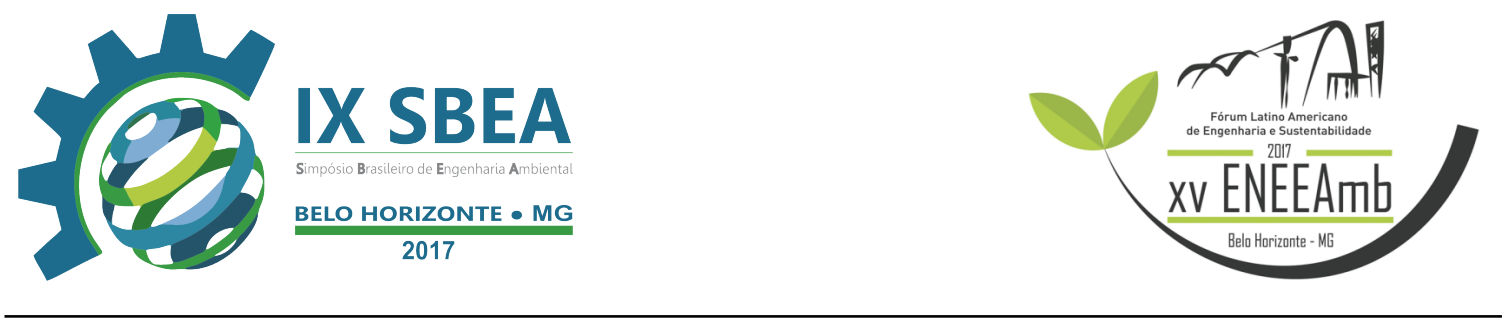

de contaminação ambiental para o meio ambiente e para a saúde da população e é preciso estudo/ações para melhoria dos cemitérios existentes. Seus problemas envolvem contaminação hídrica, dos solos e poluição atmosférica, estes pouco conhecidos pela maioria da população.

Diante do que foi dito, é preciso que os órgãos governamentais fiscalizem e penalizem os cemitérios que não se adequarem as normas da legislação e exijam que essas sejam cumpridas.

Que haja o monitoramento constante dos solos e águas nas áreas dos cemitérios construídos irregularmente, sem estudo de solo, sem impermeabilização, etc, a fim de evidenciar os impactos que a falta de planejamento acarreta no meio ambiente.

O costume de enterrar os mortos, além de tradicional é uma questão religiosa e socioeconômica. Vale ressaltar que a cremação seria a forma que causaria menor impacto ambiental, por gerar resíduos tóxicos e por possuir filtros que eliminar microrganismos patogênicos que o sepultamento convencional apresenta. As elevadas temperaturas da cremação eliminam por completo essas fontes naturais de poluição.

\section{REFERÊNCIAS BIBLIOGRÁFICAS}

ALEXANDRINO, R. R. Análise comparativa dos cemitérios de Campina Grande-PB à luz da Resolução Conama 335/2003. 2016.

BRAZ, V.; BECKMANN, L.; COSTA, L. Integração de resultados bacteriológicos e geofísicos na investigação da contaminação de águas por cemitérios. Águas Subterrâneas, 2000.

DA CUNHA KEMERICH, P. D. et al. The environmental issue involving cemeteries in Brazil. Monografias Ambientais, v. 13, n. 4, p. 3777-3785, 2014.

DE ALMEIDA, M. D. G. Memórias, lembranças, imagens: o cemitério. Estudos IberoAmericanos, v. 30, n. 1, p. 105-122, 2016. 


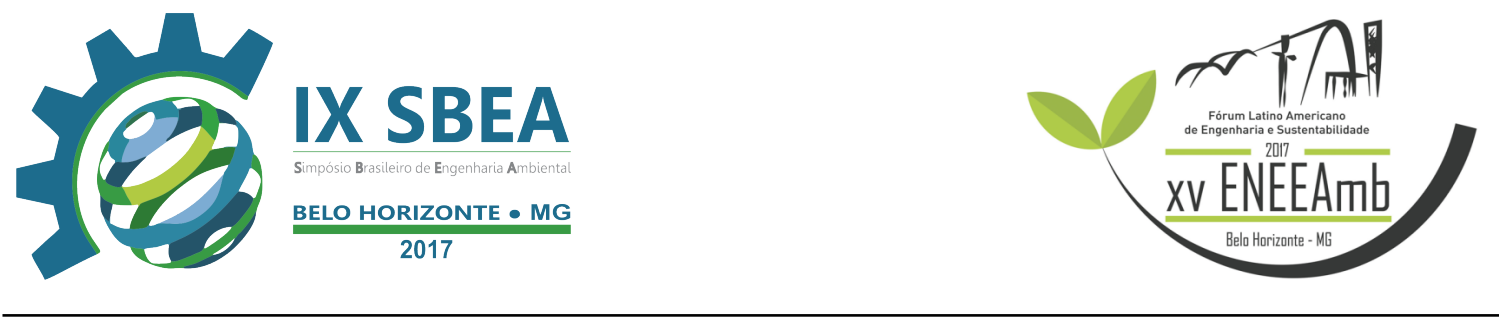

DOS SANTOS, A. G. D. S.; MORAES, L. R. S.; DE MORAIS NASCIMENTO, S. S. A. Qualidade da Água Subterrânea e Necrochorume no Entorno do Cemitério do Campo Santo em Salvador/BA. Revista Eletrônica de Gestão e Tecnologias Ambientais, v. 3, n. 1, p. 39-60, 2015.

FERRARI, J. N. et al. CEMITÉRIOS HORIZONTAIS E VERTICAIS: peculiaridades, impactos ambientais e melhores práticas DOI: http://dx. doi. org/10.5892/ruvrd. v13i1. 2425. Revista da Universidade Vale do Rio Verde, v. 13, n. 2, p. 681-688, 2015.

KEMERICH, P.; UCKER, F.; BORBA, W. Cemitérios como fonte de contaminação ambiental. Scientific American Brasil, São Paulo, v. 1, p. 78-81, 2012.

LELI, I. T. et al. Estudos ambientais para cemitérios: indicadores, áreas de influência e impactos ambientais-doi: 10.4025/bolgeogr. v30i1. 16348. Boletim de Geografia, v. 30, n. 1, p. 45-54, 2012.

SILVA, V. D. et al. Um olhar sobre as Necrópoles e seus Impactos Ambientais. III Encontro da ANPPAS, Brasília-DF, de, v. 23, 2006.

TORMEN, A. F.; TASSO, C. A.; KORF, E. P. ESTUDO DA CONTAMINAÇÃO DE ÁGUAS SUBTERRÂNEAS POR CEMITÉRIOS. Exatas \& Engenharia, v. 6, n. 16, 2017. 